\title{
URban Biotopes of Aotearoa New Zealand (URBANZ) II: Floristics, biodiversity and conservation values of urban residential and public woodlands, Christchurch
}

\author{
G.H. Stewarta,b,_, C.D. Meurkc, M.E. Ignatievaa,b, H.L. Buckleya, A. Magueurd, \\ B.S. Casea, M. Hudsona, M. Parkera \\ aLincoln University, PO Box 84, Christchurch 7647, New Zealand \\ bNew Zealand Research Centre for Urban Ecology, 178 Days Road, Springston RD4, Christchurch 7674, New \\ Zealand \\ cLandcare Research, PO Box 40, Lincoln 7640, Christchurch, New Zealand \\ dinstitut National Agronomique, Paris-Grignon, France
}

\begin{abstract}
Urban forests are increasingly valued for multiple benefits such as amenity, cultural values, native biodiversity, ecosystem services, and carbon sequestration. Urban biodiversity in particular, is the new focus although global homogenisation is undermining regional differentiation. In the northern hemisphere (e.g., Canada and USA) and in the southern hemisphere, particularly in countries like South Africa, Australia, South America and New Zealand, local biodiversity is further impacted by historical colonisation from Europe. After several centuries, urban forests are now composed of synthetic and spontaneous mixtures of native species, and exotic species from around the temperate world (e.g., Europe, North and South America, South Africa, Asia). As far as we are aware no-one has carried out in-depth study of these synthetic forests in any Southern Hemisphere city. Here we describe the composition, structure, and biodiversity conservation imperatives of urban temperate forests at 90 random locations in Christchurch city, New Zealand.
\end{abstract}

We document considerable plant diversity; the total number of species encountered in the 253 sampled urban forest patches was 486 . Despite this incredibly variable data set, our ability to explain variation in species richness was surprisingly good and clearly indicates that total species richness was higher in larger patches with greater litter and vegetation cover, and taller canopy height. Species richness was also higher in patches surrounded by higher population densities and closer to very large native forest patches. Native species richness was higher in patches with higher soil $\mathrm{pH}$, lower canopy height, and greater litter cover and in patches closer to very large native forest patches indicating dispersal out of native areas and into gardens. Eight distinct forest communities were identified by Two-Way INdicator SPecies ANalysis (TWINSPAN) using the occurrence of 241 species that occurred in more than two out of all 253 forest patches.

Christchurch urban forest canopies were dominated by exotic tree species in parklands and in street tree plantings (linear parkland). Native tree and shrub species were not as common in public spaces but their overall density high in residential gardens. There was some explanatory power in our data, since less deprivation resulted in greater diversity and density, and more native species, which in turn is associated with private ownership. We hypothesise that a number of other factors, which were not well reflected in our measured environmental variables, are responsible for much of the remaining variation in the plant community structure, e.g., advertising, peoples choice. For a more sustainable asset base of native trees in New Zealand cities we need more, longer-lived native species, in large public spaces, including a greater proportion of species that bear fruit and nectar suitable for native wildlife. We may then achieve cities with ecological integrity that present multiple historical dimensions, and sequester carbon in legible landscapes.

Keywords: Native/exotic species; New Zealand; Parkland; Urban forest; Woodland 


\section{Introduction}

Urban forests are increasingly valued for multiple benefits such as amenity and cultural values, native biodiversity and other ecosystems services, and carbon sequestration (Konijnendijk et al., 2005). Urban biodiversity in particular, is the new focus for implementing the Convention on Biological Diversity (Anonymous, 2008). However, globalisation trends are causing cities and towns to become homogenised with species from around the world which undermines regional differentiation (Stewart et al., 2007). This is particularly apparent in countries like the USA, Canada, Australia, and New Zealand that were colonised from Europe and the process is continuing with unprecedented mobilisation of the world's people (Stewart et al., 2007). European settlers applied to these diverse lands the exact same principles of urban design and land use practice, and landscape and planting design principles, not to mention their tried and tested species that they had employed in Europe (Ignatieva and Stewart, in press). Many southern hemisphere colonial cities, such as Christchurch (New Zealand), Cape Town (South Africa), and Adelaide (Australia), were planned from Europe and the land cleared of native vegetation before city establishment. Some cities (e.g., Canberra, Australia) were planned for special reasons (as the capital city of Australia in this case). As a result of the land clearances and imported urban planning precepts many colonial cities have little native forest remaining. Small patches of forest have been preserved in some cities, for example, Kings Park in Perth, Australia, Riccarton Bush in Christchurch, New Zealand, and Claudelands Bush in Hamilton, New Zealand.

The use of similar design structures, landscape architecture styles, plant material, and construction materials has resulted in the creation of common vegetation units, habitats, or urban biotopes as they have been termed in Europe. These include lawns, woodlands, shrubberies, hedges, flowerbeds, herbaceous borders, roadside and railway verges, walls, and paving cracks. So, after several centuries since colonisation urban biotopes such as forests and woodlands are now composed of mixtures of native and exotic species from around the temperate world (e.g., Europe, North and South America, South Africa, Asia). As in Europe these are now synthetic communities of planted and spontaneous species. Thus, the New Zealand Christmas tree (pohutakawa, Metrosideros excelsa Sol. ex Gaertn.) along sidewalks and Pittosporum tenuifolium Sol.ex Gaertn. in woodlands, can be seen in San Francisco, USA and the pin oak (Quercus palustris Muenchh.) from the north-eastern USA is prevalent in New Zealand woodlands and parks.

Urban ecology is a young science in New Zealand and yet ecological principles are as valid in cities as they are in primeval wilderness, and indeed should be better understood to manage the increasing environmental and social problems in burgeoning cities. The invasion and naturalisation of exotic species in New Zealand is unique and a serious conservation issue. The native flora of New Zealand is $80 \%+$ endemic and highly susceptible to displacement by invasive exotic species that perform well in the benign climate. Thus, we place particular emphasis in this paper on the issue of native vs. exotic species when considering species richness and biodiversity.

This paper is the second in a series describing the structure, composition, biodiversity conservation imperatives, and management implications of urban ecosystems in New Zealand (also see de Neef et al., 2008; Stewart et al., in press). Here we characterise urban forests in Christchurch city, the second largest urban environment in the country, and ask the following questions:

(1) What is the composition and species diversity of urban woodlands and parklands?

(2) What is the mix of native and exotic species?

(3) What environmental and social factors determine woodland and parkland composition?

(4) What are the conservation values and management implications for these urban forests? 


\section{Methods}

\section{Field sampling}

We sampled restoration forest, planted native woodland, gardens, residential woodland, park and street woodlands, and plantation forest (conifer, eucalypt, other hardwoods), but not natural or primary forest remnants. Only 'forests' $>100 \mathrm{~m}^{2}$ were sampled. The forests were classified into three types: (1) 'Woodland' was open forest, of deciduous and/or evergreen trees in which tree canopy gaps were less than 5 times the mean height of the canopy, and under which there was an 'unmanaged' understorey of scattered shrubs and ground covers of ferns, grasses and spring flowers. (2) 'Parkland' was open forest or woodland (as above) in which there was no woody understorey, but ground cover of ferns, grass and/or other herbaceous species and spring flowers that are somewhat shade-tolerant and generally mown. (3) 'Linear parkland' (street planting, alley) comprised lines of trees (isolated from other tall woody vegetation) in which the tree canopy gaps were between 0.5 and 1.5 times the canopy height. If woodlands had canopy gaps greater than 5 times the mean canopy height or linear parklands had gaps greater than 1.5 times the mean canopy height then they were not treated as 'forest' for the purpose of this study and were not surveyed.

We used a stratified random sampling scheme to identify target urban forest patches by selecting a random point in each 2_2 km grid square of the Christchurch city map excluding the Central Business District $(6.0 \mathrm{~km} 2)$. A total of $272 \mathrm{~km} 2$ was therefore covered for greater Christchurch (one random point per $3.4 \mathrm{~km} 2$ ) and in the CBD we sampled more intensively (one random point per $0.5 \mathrm{~km} 2$ ). The nearest residential property to the random point was chosen for sampling and the nearest public or other place such as a park or school that had a woodland and/or parkland and/or linear parkland was also sampled if one occurred within $500 \mathrm{~m}$ of the random point. Consequently, a total of 253 urban forest patches were sampled at 90 random points throughout the city (Fig. 1, see also Stewart et al., in press).

The species composition of each urban forest patch was determined by sampling the entire patch. For woodlands, all species were recorded. For parklands and linear parklands all trees/shrubs were recorded but in the herbaceous understory only the six most abundant species were recorded. The complete composition of the herbaceous layer (lawn) in linear parklands and parklands was not sampled as this is covered in detail in Stewart et al. (in press). Variation in the composition of lawns is discussed in relation to linear parklands and parklands in the Discussion section.

For each forest area we recorded the following variables: forest category (woodland, parkland, linear parkland), ownership (residential, public, 'other'), suburb name from a Christchurch city map, street name, and the number of the property. 'Other' ownership included schools, commercial sites, and golf courses. A handheld GPS was used to map the position of forest area boundaries. In addition, we recorded the following environmental data at each patch: altitude (metres above sea level), slope (estimated in degrees), aspect (N, NW, NE, W, E, SW, SE, S), drainage (good, medium, poor), soil type, soil $\mathrm{pH}$ (field indicator test), a relative index of site frostiness (indices based on the known behaviour of cold air as a function of topography, e.g., the steeper and longer the slope, the less frosty), canopy cover (\%), cover of litter/vascular plants/moss/bare ground/rock (\%), mean canopy height (uppermost tier, in metres), and relative basal area (low, medium or high). GPS locations delimiting forest patch boundaries were imported into ArcGIS 9.1 GIS software (ESRI, 2004) and forest area, perimeter, and shape (ratio of area to perimeter) were computed. We also used the GIS to compute the distance to the nearest large native forest patch, distance to the coast, distance to the Central Business District (CBD), and mean \% cover of impervious surface in a 500m buffer derived from Landsat 7 satellite imagery. We attempted to incorporate social influences on these forest patches by collating some coarse social variables. The GIS was used to derive two variables based on Statistic New Zealand's (2001) census data and digital census unit boundaries: mean human population density in a $500 \mathrm{~m}$ buffer around the sample site and mean deprivation index in a $500 \mathrm{~m}$ buffer. The latter index is derived from combining nine measures of relative 'social disadvantage' based on the 2001 census data (Salmond and Crampton, 2002). 
Fig. 1. Map of Christchurch city, New Zealand, showing the location of the 90 random sample locations and an enlargement of the central city showing (in red) an example of the urban forest patches sampled. (For interpretation of the references to colour in this figure legend, the reader is referred to the web version of this article.)

Fig. 2. The number of forest patches in Christchurch out of 253 in which all 486 species occurred. Note that approximately 180 species occurred only at one site. (Refer to the web version of this article.)

Data analysis

We classified urban forest patches into community types based on their species composition by performing a Two-Way INdicator SPecies ANalysis (TWINSPAN) using the occurrences of 241 species in the 253 forest patches sampled in the statistical software package PCORD for Windows, version 4.17 (McCune and Mefford, 1999). We excluded a further 245 rare species from the analysis that occurred in fewer than three forest patches. TWINSPAN split the set of forest patches based on the occurrences of 'indicator species' (Hill, 1979).

Detrended Correspondence Analyses (DCA) was used to assess the pattern of species composition across forest patches using the presence of all 486 species in all 253 sites. However, this analysis was relatively uninformative because it was driven by the occurrences of rare species (174 species only occurred once, Fig. 2). We therefore analysed all sites but only species that occurred in greater than two sites (241 spp) of the 'forests' sampled.

To determine the most important environmental and/or social variables driving patterns of 'forest' species composition, a Canonical Correspondence Analysis (CCA) was performed using all sites and only the 241 species that occurred in greater than 2 sites. The DCA and CCA ordinations were performed using CANOCO for Windows Version 4.5 (ter Braak and Smilauer, 2002).

To investigate patterns of species richness we used backwards stepwise selection in a least squares regression to relate log-transformed species richness of all species $\left(n \frac{1}{4} 486\right)$ in all sites $\left(n \frac{1}{4} 253\right)$ and log-transformed species richness of native species ( $n$ 1/4 106) in sites containing natives ( $n$ 1 $1 / 4161)$ to the measured environmental and social variables. Only variables that were uncorrelated were used in the regressions to avoid the effects of collinearity and only those variables that were significant at Po0.05 were retained in the final model.

Results

Species richness

Of the 253 sites sampled, 137 were public spaces, 75 were residential properties and 41 were under 'other' ownership. We encountered twice as many woodland sites as either parkland or linear parkland (Table 1a). Species richness was highest in woodlands and lowest in linear parklands. Mean species richness in woodland patches was almost double that of parklands and three times that of linear parklands. Overall, exotic species dominated, with $80 \%$ frequency compared to the proportion of native species overall which was quite low (20\%). However, the proportion of native species was $50 \%$ higher in woodland than parkland or linear parkland and the number of native species in woodland was approximately three times that of parkland (Table 1a). Linear parklands were characterised by exotic trees and herbaceous plants (78\% of all species), parklands by exotic trees, shrubs and herbaceous plants (84\%), and woodlands by exotic and native trees and shrubs (76\%, Table 1b). These patterns highlight woody species richness; the herbaceous species richness of lawns that occurred in parklands and linear parklands was much lower and native species were virtually absent (see Stewart et al., in press and the Discussion).

Table 1 (a) Species richness, SD is the standard deviation, and (b) exotic and native species by life forms in urban forests, Christchurch, New Zealand. $n=$ total number of species by urban forest type. (Refer to the web version of this article.) 
Table 2. Minimum adequate model statistics from a backwards stepwise selection using least squares regression to relate (a) log transformed species richness of all species $(n=486)$ in all forest patches $(n=253)$ and $(b)$ logtransformed species richness of native species $(n=106)$ in forest patches containing native species $(n=161)$ to the measured environmental and social variables. P-values are when variables are included last in the model. The model $R^{2}$ value for (a) all species was 0.37 and for (b) native species was 0.30 .

(Refer to the web version of this article.)

\section{Explanations for patterns in species richness}

In the multiple regression, a number of the environmental variables explained $37 \%$ of the variation in the richness of all species in the 253 forest patches (Table 2). Residential forest patches had higher total species richness than 'other' and public owned patches, which did not differ significantly from each other (Fig. 3a). Total species richness was higher in larger patches with greater litter and vegetation cover, and taller canopy height. Species richness was higher in patches surrounded by higher population densities and closer to very large native forest patches. Low basal area 'forests' had lower species richness than medium and high basal area 'forests', which did not differ significantly from each other.

When native species were considered independently, environmental variables explained $30 \%$ of the variation in patch species richness (Table 2). Interestingly, patch ownership did not enter the final model, but rather, the results showed that native species richness was higher in patches with higher soil $\mathrm{pH}$, lower canopy height, and greater litter cover. In addition, native species richness was higher in patches that were close to very large native forest patches and patches with low basal area had fewer native species than patches with either medium or high basal area (Fig. 3b).

\section{Species composition}

The canopies of Christchurch urban forest patches were dominated by a tremendous array of planted exotic tree species (Table 3). Species of the hardwood genera Acer, Betula, Quercus, Prunus, Ulmus, Fraxinus, and Eucalyptus were all common dominants, along with a host of cupressoid conifers including the genera Cupressus, Chamaecyparis, Cedrus, and Thuja. Note that several native tree species were also significant canopy dominants, including Sophora, Nothofagus, and Podocarpus (Table 3).

Although there were many more exotic than native species, twelve of the twenty species that occurred most frequently in patches were native (Table 4). Of the twenty most frequent woody species, 15 were native; including the three most abundant which were Pittosporum tenuifolium Sol.ex Gaertn., Cordyline australis (Forst.f.) Endl., and Pittosporum eugenioides A. Cunn. with patch occupancies of between $31 \%$ and $39 \%$. Although native species were abundant in many urban forests, many occurred in the lower tiers as seedlings, saplings, and small trees (many are not planted but arrive at a site via bird dispersal, see Stewart et al., 2004). The five most frequent exotic species were Betula pendula Roth, Sambucus nigra Linnaeus, Hedera helix L., Camellia japonica L., and Acer pseudoplatanus L. Surprisingly, one of the characteristic exotic tree species of public parks and street sidewalks in Christchurch, Quercus robur L., had a frequency of only $10 \%$.

\section{Community types}

We recognised eight types of urban forest (Fig. 4). The TWINSPAN analysis split the data set initially by the presence (linear parkland and parkland) or absence (woodlands) of the indicator species Trifolium repens L. and Lolium perenne L. Further divisions between shelterbelts and parklands occurred due to the presence or absence of Pinus radiata D. Don and Eucalyptus spp. and the herbaceous species Lolium perenne L. and Trifolium repens L. In the woodland group, the key indicator species that separated native from exoticdominated woodlands were Pittosporum spp. and Cordyline australis (Forst.f.) Endl. (both native) and a host of exotic ornamentals such as Rhododendron spp., Camellia japonica L. and Iris spp. 
Shelterbelts contained various mixtures of exotic conifers, eucalypts and other deciduous hardwoods, with occasional weedy shrubs such as Ulex europaeus L. (Table 5). Parklands were typically dominated by Betula pendula Roth, Quercus spp., and Acer spp., with a minimal shrub layer and a 'lawn' ground cover dominated by Achillea millefolium L., Holcus lanatus L., Dactylis glomerata L., Bellis perennis L., and Taraxacum officinale Cass. Some garden woodlands were dominated by the exotics Betula pendula Roth, Fagus sylvatica L., and Magnolia grandiflora L., the bird dispersed Prunus spp., a host of shrubs popularly cultivated for colourful displays such as Rhododendron, Camellia, Hydrangea, and Viburnum and also colourful groundcovers such as Iris and Lilium spp., Other garden woodlands were dominated by native canopies containing Pittosporum spp., Plagianthus regius (Poit.) Hochr., and North Island Hoheria populnea A. Cunn. and diverse shrub tiers with Solanum laciniatum Ait. and Brachyglottis greyi (Hook. f.) and the native flax (Phormium tenax J.R. et G. Forst.).

Insert table 3 \& 4

Figure 4

(Refer to the web version of this article.)

Semi-wild mixed woodlands contained complexes of exotic conifers and willows, native Pittosporum and Plagianthus above shrub tiers containing Cytisus scoparius L. (Link), Sambucus nigra Linnaeus, native Hebe spp., and Ulex europaeus L. The presence of the exotic shrubs Cytisus, Rubus, and Ulex and the vine Hedera helix L. indicates a low level of management as these species are invasive if not removed. Other species that were prominent in mixed coastal woodlands included natives such as Dodonaea viscosa Jacquin, Metrosideros excelsa Sol. Ex Gaetrn. and Olearia paniculata (J.R. et G. Forst.) Druce and exotic Tamarix parviflora DC., Arbutus unedo L., and Chrysanthemoides monilifera (L.) T. Nord.

Native species were abundant in only three community types: native-dominated garden woodland, semiwild mixed woodland, and coastal mixed woodland (Table 5). Most of these abundant natives were tree species (14 species) with only five shrub species prevalent along with the liliaceous Phormium tenax J.R. et G. Forst. Shelterbelts, parklands, and exotic-dominated garden woodlands contained very few prominent native species and were dominated by exotic species. Twenty seven exotic conifers (Pinus, Cedrus, Cupressus, Pseudotsuga and hardwoods from genera such as Acacia, Salix, Betula, Populus, Quercus, and llex dominated these communities.

Explanations for compositional variation in urban forests

The Detrended correspondence analysis showed that there was extreme complexity in this data set (Table 5); gradient lengths for the first four axes were very long reflecting the massive turnover in species among patches. The first axis appeared to largely reflect the considerable differences in species composition between woodlands, and parklands and linear parklands (Fig. 5). The very low values for the percent variance explained by the DCA are likely to be due primarily to the extremely large number of sites and species (Leps and Smilauer, 2003).

When we compared the CCA results to those from the DCA the first four axes explained less than 4\% of the variation in species composition and the species-environment correlations were relatively low, indicating that the measured environmental variables were not likely to be the most important drivers of this variation (Table 6). However, when considering the massive amount of variation encompassed by the data set, this is not a surprising result and we suggest that the significant environmental variables shown in the ordination diagrams do account for important ecological variation among these communities.

Table 5 Insert

(Refer to the web version of this article.)

The CCA biplot of the species data illustrates quite clearly a separation between types of urban forest (Figs. 6 and 7). The coastal species typical of mixed coastal woodland appear low on axis 2 reflecting agradient of distance from the coast (Fig. 6). These species include Myoporum laetum Forst. f. 
(myolae), Coprosma repens A. Rich. (coprep), Olearia paniculata (J.R. et G. Forst.) Druce (olepan), Phormium tenax J.R. et G. Forst. (photen), Dodonea viscosa Jacquin (dodvis), Cordyline australis (Forst.f.) Endl. (coraus), Pittosporum crassifolium Banks et Sol. ex A. Cunn. (pitcra), Griselinia littoralis Raoul (grilit), and Agapanthus orientalis F.M. Leighton (agaori). The linear parklands and parklands that included a dominance of coarse, weedy grasses such as Bromus wildenowii Kunth (browil) and various flatweeds beneath typical fast-growing deciduous broadleaved trees such as Quercus robur $\mathrm{L}$. (querob), Fraxinus excelsior L. (fraexc), Acer pseudoplatanus L. (acepla), Betula pendula Roth (betpen), and native Plagianthus regius (Poit.) Hochr. (plareg) occurred on the left of the CCA diagram. Woodlands (high values on axis 1) had mixes of native and exotic understorey or low canopy species, such as Camellia japonica L. (camjap), Prunus cerasifera Ehrh. (prucer), Sambus nigra Linnaeus (samnig), Hedera helix L. (hedhel), and several native and exotic trees and shrubs, such as Rhododendron spp (rhospp), Fatsia japonica (Thunb.) Deone. Planch. (fatjap), Iris spp. (irispp) and the fern Dryopteris filix - mas (L.) Schott (dryfil).

The impact of forest patch ownership was reflected in denser forest patches being more prevalent in private residential properties, whereas public and commercial ownership was associated with more open parklands (Fig. 7). Dense forest patches, especially those with significant native species, therefore occurred more often on residential properties. This trend was stronger in poorer parts of the city where dense woodlands were less frequent. This is reflected in the greater deprivation index being associated with linear and wider parklands. Not surprisingly, patch shape (breadth) was greater in woodlands and least in linear parklands. There were more native patches away from the coast so accordingly distance to the nearest native patch was greatest near the coast where the main large areas of forest were exotic plantations.

\section{Discussion}

Christchurch urban forest canopies were dominated by exotic tree species in parklands and in street tree plantings (linear parkland). Native tree and shrub species were not as common in public spaces (except for native habitat restoration sites) but more frequent in the lower forest tiers of woodlands that dominated in residential gardens (Table 1b). Our analysis clearly distinguished eight discrete communities based on significant native-exotic species differences.

Our study is somewhat different to others in that we sampled all urban woodlands including residential, public and institutional sites (but see Turner et al., 2005). Residential gardens and woodlands within urban Christchurch appear to be 'hotspots' for native woody biodiversity and equally a great array of unusual as well as rare exotic and native species. Many of these species require adequate shelter, moisture, and favourable conditions for establishment and only the nurturing (or neglect) of environments of residential woodlands provides this. One Fendalton garden we examined in 2004 had native Podocarpus totara G. Benn. ex D. Don and Pseudopanax seedlings emerging from an exotic Hydrangea shrub border. In Auckland city proportional density of native trees is around 25\% (Meurk et al., in press). Turner et al. (2005) also noted higher species richness in residential areas but whereas we documented considerable native species richness in their study alien taxa dominated.

Urban forests can contain considerable diversity (Godefroid and Koedam, 2003; Cornelis and Hermy, 2004; Alvey, 2006). In Guangzhou City, China, Jim and Liu (2001) found 254 species in their sample of over 115,000 trees in parks, institutional sites and along city streets. Zerbe et al. (2003) showed that the highest numbers of species in Berlin were found between the city centre and the outskirts where open spaces like parks, urban forests and wastelands were more common. Jim and Chen (2008) recorded 164 species in urban forests in Taipei with urban parks exhibiting the highest species richness. In many instances high socio-economic status has been shown to increase species diversity (Luz de la Maza et al., 2002; Pedlowski et al., 2002), whilst in others patch area and site age might have significant relationships with species diversity (Hermy and Cornelis, 2000). Other influences include site topography, evolving landscape fashion, funding constraints, historical legacies, natural and anthropogenic disturbances, and changing site conditions (Jim and Liu, 2001). 
We also document considerable plant diversity in the urban forests of Christchurch; the total number of species encountered in the 253 sampled patches was 486. Urban residential woodlands were especially rich in species. Parklands and linear parklands were less species rich, which in part reflects our sampling strategy since we only sampled the 6 most abundant herbaceous species in the ground cover or 'lawn layer'. However, native species are extremely rare in these lawns (only 9 found in 127 lawns) where c. $40 \%$ of all species were only encountered once (Stewart et al., in press). The exotic grasses and forbs Trifolium repens L., Lolium perenne L., Agrostis capillaris L., Taraxicum officinale Cass., Bromus wildenowii Kunth, Poa annua L., Festuca rubra L., Achillea millefolium L., and Trifolium dubium Sibth. dominated in $450 \%$ of all lawns (Stewart et al., in press). So even accounting for our sampling strategy parklands and linear parklands are considerably less diverse than woodlands.

Despite our incredibly variable data set, our ability to explain variation in species richness was surprisingly good and clearly indicates some of the key drivers structuring these communities. Clearly a suite of environmental variables including soil $\mathrm{pH}$ and litter cover strongly influence patterns of native species richness. More natives were found near native forest patches indicating that native species are dispersing out of native areas and into gardens. The correlation with litter and basal area seems to suggest that denser gardens may have more natives whereas the negative correlation with canopy height probably just reflects the higher number of natives used in 'new' plantings that have not yet grown to maturity. Deprivation index and ownership appear to dictate vegetation structure. Total and native species richness was greatest in woodlands (primarily residential) and least in linear parklands. Several studies have shown that socioeconomics (such as family income and household age and associated lot size) drives urban plant diversity - the 'luxury effect' (Hope et al., 2003). Household income was also deemed to be a key driver of plant diversity in Tasmanian front yards (Kirkpatrick et al., 2007) and household income and household density were implicated as important correlates by Iverson and Cook (2000). There is some explanatory power in our data here, since less deprivation resulted in greater diversity and density, and more native species, which in turn is associated with private ownership (also see Pedlowski et al., 2002).

When variation in species identities were taken into account in the ordination analysis, the DCA showed the extreme nature of this variation in long gradient lengths (Table 6) indicating massive turnover in species composition among patches. When the DCA results are compared to the CCA results we can see that although our overall explanatory power is low (the first two axes of the CCA explain only $2.6 \%$ of the variation in patch species composition), the range of significant explanatory variables does point to several processes in particular that may be driving at least some of this variation. These factors include ownership in the first instance, but also distance to the coast, distance to the nearest native patch, patch shape and the deprivation index.

We hypothesise that a number of other factors, which were not well reflected in our measured environmental variables, are responsible for much of the remaining variation in the plant community structure in Christchurch urban residential forest patches. First, Christchurch is often referred to as the 'garden city', gardening is the second most preferred pastime for residents in New Zealand, after walking. Residents are subjected to media promotions (TV and radio gardening programmes, newspaper excerpts on gardening, gardening magazines) and over 70 nurseries in the Christchurch region provide advertisements and catalogues on the most popular garden plants. The plant industry leads garden style in much the same way as clothing fashion houses promote the new year's 'hot' colour, texture, style or 'cultivar' (cf. Turner et al., 2005). There are numerous garden clubs that meet regularly and at these meetings, plants are swapped or sold. Residential neighbours frequently trade or swap plants. A preliminary survey that we conducted suggests that as little as $20-40 \%$ of plants that are incorporated into residential gardens are actually purchased from a nursery or other outlet (McGaw, 2007). In the nursery industry in New Zealand, demand for plants is strongly driven by plant fashion and supply by economic criteria. That probably explains, at least in part why many native species in Christchurch city have been sourced from outside the local area, particularly from the North Island of New Zealand. It is also noteworthy that, because gardening modifies the physical environment by irrigation, cultivation, fertiliser and herbicide use, and the provision of shelter, gardens themselves are homogenised according to fashion regardless of natural soil moisture or fertility. 
Our results show that native species are surprisingly abundant in Christchurch, particularly in residential gardens. This can be attributed in part to a wider and successful education programme on the value of native biodiversity, the waterway enhancement programme of the 1990s, and the rise in the number of dedicated native plant nurseries. Residents are now planting more native species (Steve Bush, pers. comm.). However, this change in attitude may also be attributed increasingly to the natural regeneration processes that are occurring as more source plants mature and bear fruit. Fiftythree percent of native New Zealand species are fleshy fruited or nectar bearing and for woody species alone, the figure is greater than 75\% (Burrows, 1994). Exotic and native birds present in the city are responsible for distributing these native species around residential gardens (Williams and Karl, 2002). The native wildlife is coadapted to the resources of native trees and shrubs. Eleven of the 15 native species that occurred in the most frequently occurring 20 woody species found in Christchurch are nectar-bearing or produce fleshy fruits. By contrast, the majority of exotic species that have been planted in Christchurch have little or no value to native wildlife as they are predominantly dry-fruited and wind- or gravity-dispersed (Stewart et al., 2004).

However, a few exotic species produce fleshy fruits for example, Sambucus nigra Linnaeus, Hedera, Taxus, Prunus, Fatsia and llex and birds have rapidly spread them in urban environments so that they are now naturalised. In addition, some of the exotic tree species have adverse health benefits (D'Amato et al., 1998). For example, one of the most abundant exotic tree species Betula pendula Roth (as well as Platanus) is known to cause a host of allergy related problems for people (D'Amato et al., 1998). We believe that with appropriate management, Christchurch's native tree and shrub species could become significantly more common in urban forests (cf. Stewart et al., 2004). This will involve public education because often residents do not know whether species are native or not, and what the values of native species might be to native wildlife (author results, unpublished). Parkland and linear parkland composition is driven by decisions made by local authorities, in our case, the Christchurch City Council. Over 90,000 trees have been planted in Christchurch city streets and parks and over $80 \%$ of these trees are exotic species (Stewart et al., 2004). This dominance of exotic species in parks and streets is borne out by this research (Fig. 6). A recent survey we conducted along a main street in one of the wealthier suburbs of Christchurch City (Fendalton Road) indicated that approximately $5 \%$ of new city council plantings were native compared to approximately $40 \%$ of older plantings (many of which had been incorporated into the street from former private gardens). The overall picture seems to suggest that particularly the 'wealthy' communities of Christchurch are more pro-native than the administrative or political leadership. Residents vote with their planting choices regardless of the marketing pressure which may be targeted more at lower socio-economic communities - rapid turnover, low cost consumerism as opposed to longer enduring 'heritage' native trees for 'heritage' properties. There is also a lag in government thinking because bureaucracies are notoriously conservative and 'riskaverse'. For a more sustainable asset base of native trees in New Zealand cities we need more, longer-lived native 'heritage' species, in large public spaces, including a greater proportion of species that bear fruit and nectar suitable for native wildlife. Only then will we have achieved cities with ecological integrity, multiple historical dimensions, and the ability to sequester carbon in legible landscapes (also see Turner et al., 2005; Alvey, 2006).

\section{Acknowledgements}

This research was funded by a subcontract to Manaaki Whenua-Landcare Research as part of a Foundation for Research, Science and Technology (FRST) programme on Low Impact Urban Design and Development (CO9X0309). We are grateful to the Institut National Agronomique, Paris-Grignon, France for providing the funding for one of us (Anaelle Magueur) to be involved in the project.

\section{References}

Alvey, A.A., 2006. Promoting and preserving biodiversity in the urban forest. Urban Forestry and Urban Greening 5, 195-201.

Anonymous, 2008. Urban Biodiversity and Design: implementing the convention on biological diversity in towns and cities. International conference, Erfurt, Germany, 21-24 May 2008. Retrieved May 26, 2009, from /http://www.fh-erfurt.de/urbio/httpdocs/content/invitation.phpS. 
Burrows, C.J., 1994. Fruit types and seed dispersal modes of woody plants in Ahuriri Summit Bush, Port Hills, Western Banks Peninsula, Canterbury, New Zealand. New Zealand Journal of Botany 32, 169-181.

Cornelis, J., Hermy, M., 2004. Biodiversity relationships in urban and suburban parks in Flanders. Landscape and Urban Planning 69, 385-401.

D’Amato, G., Spieksma, F., Liccardi, G., Jager, S., Russo, M., Kontou-Fili, K., Nikkels, H., Wuthrich, B., Bonini, S., 1998. Pollen-related allergy in Europe. Allergy 53 (6), 567-578.

de Neef, D., Stewart, G.H., Meurk, C.D., 2008. Urban Biotopes of Aotearoa New Zealand (URBANZ) (III): Spontaneous urban wall vegetation in Christchurch and Dunedin. Phyton (Horn, Austria) 48, 133-154.

ESRI, 2004. ArcGIS 9.1 Software. Environmental Systems Research Institute Inc., Redlands, CA.

Godefroid, S., Koedam, N., 2003. Distribution pattern of the flora in the peri-urban forest: an effect of the city-forest ecotone. Landscape and Urban Planning 65, 169-185.

Hermy, M., Cornelis, J., 2000. Towards a monitoring method and a number of multifaceted and hierarchial biodiversity indicators for urban and suburban parks. Landscape and Urban Planning 49, 149-162.

Hill, M.O., 1979. TWINSPAN - a FORTRAN program for arranging multivariate data in an ordered twoway table by classification of the individuals and attributes. Cornell University, Ithaca, NY.

Hope, D., Gries, C., Zhu, W., Fagan, W.F., Redman, C.L., Grimm, N.B., Nelson, A.L., Martin, C., Kinzig, A., 2003. Socioeconomics drives urban plant diversity. Proceedings of the National Academy of Sciences of the United States of America (PNAS) 100, 8788-8792.

Ignatieva, M.E., Stewart, G.H., in press. Homogeneity of urban biotopes and similarity of landscape design language in former colonial cities. In: McDonnell, M.J., Hahs, A., Breuste, J. (Eds.), Comparative Ecology of Cities and Towns. Cambridge University Press, Cambridge.

Iverson, L.R., Cook, E.A., 2000. Urban forest cover of the Chicago region and its relation to household density and income. Urban Ecosystems 4, 105-124.

Jim, C.Y., Liu, H.T., 2001. Species diversity of three major urban forest types in Guangzhou City, China. Forest Ecology and Management 146, 99-114.

Jim, C.Y., Chen, W.Y., 2008. Pattern and divergence of tree communities in Taipei's main urban green spaces. Landscape and Urban Planning 84, 312-323.

Kirkpatrick, J.B., Daniels, G.D., Zagorski, T., 2007. Explaining variation in front gardens between suburbs of Hobart, Tasmania, Australia. Landscape and Urban Planning 79, 314-322.

Konijnendijk, C.C., Nilsson, K., Randrup, T.B., Schipperijn, J. (Eds.), 2005. Urban Forests and Trees. Springer, Heidelberg.

Leps, J., Smilauer, P., 2003. Multivariate Analysis of Ecological Data using CANOCO. Cambridge University Press, Cambridge.

Luz de la Maza, C., Herna'ndez, J., Bown, H., Rodriguez, M., Escobedo, F., 2002. Vegetation diversity in the Santiago de Chile urban ecosystem. Aboricultural Journal 26, 347-357.

McCune, B., Mefford, M.J., 1999. PC-ORD: multivariate analysis of ecological data (Version 4). MjM Software Design, Gleneden Beach, OR.

McGaw, S., 2007. Lincoln LIUDD project: Native plant choices and availability in Christchurch. Unpublished report. Lincoln University.

Meurk, C.D., Zviagina, N., Gardner, R.O., Forrester, G., Hall, G., North, H., Belliss, S., Whaley, K., Wilcox, M., Cooper, J., O'Halloran, K., Sykes, B., in press. Environmental, social and spatial determinants of urban arboreal character in Auckland, New Zealand. In: McDonnell, M.J., Hahs, A., Breuste, J. (Eds.), Comparative Ecology of Cities and Towns. Cambridge University Press, Cambridge.

Pedlowski, M.A., Corabi Adell, J.J., Heynen, N.C., 2002. Urban forest and environmental inequality in Campos dos Goytacazes, Rio de Janeiro, Brazil. Urban Ecosystems 6, 9-20.

Salmond C., Crampton, P., 2002. NZDep2001 Index of deprivation. Department of Public Health, Wellington School of Medical and Health Sciences, Wellington, New Zealand.

Statistics New Zealand 2001. Retrieved October 1, 2008, from: /http://www.stats.govt.nz/datasetsS.

Stewart, G.H., Ignatieva, M.E., Meurk, C.D., Earl, R.D., 2004. The re-emergence of indigenous forest in an urban environment, Christchurch, New Zealand. Urban Forestry and Urban Greening 2, 149158. 
Stewart, G.H., Ignatieva, M.E., Meurk, C.D., Buckley, H., Horne, B., Braddick, T., in press. URban Biotopes of Aotearoa New Zealand (URBANZ) (I): Composition and diversity of temperate urban lawns in Christchurch. Urban Ecosystems, doi:10.1007/s11252-009-0098-7.

Stewart, G., Ignatieva, M., Bowring, J., Egoz, S., Melnichuk, I. (Eds.), 2007. Globalisation and landscape architecture: issues for education and practice. Selected Abstracts and Refereed Papers From a Conference in St Petersburg State Forest Technical Academy, Russia, 3-6 June, 2007. St Petersburg State Polytechnic University Publishing House, St Petersburg.

ter Braak, C.J.F., Smilauer, P., 2002. CANOCO reference manual and CanoDraw for windows user's guide: software for canonical community ordination (version 4.5). Microcomputer Power, Ithaca.

Turner, K., Lefler, L., Freedman, B., 2005. Plant communities of selected urbanised areas of Halifax, Nova Scotia, Canada. Landscape and Urban Planning 71, 191-206.

Williams, P.A., Karl, B.J., 2002. Birds and small mammals in kanuka (Kunzea ericoides) and gorse (Ulex europaeus) scrub and the resulting seed rain and seedling dynamics. New Zealand Journal of Ecology 26, 31-41.

Zerbe, S., Maurer, U., Schmitz, S., Sukopp, H., 2003. Biodiversity in Berlin and its potential for nature conservation. Landscape and Urban Planning 62, 139-148 